\title{
The Effective Role of Vermicompost, Elemental Sulphur and Ascorbic Acid on Tomato Plants Grown on A Newly Reclaimed Calcareous Soil at Fayoum Depression
}

\author{
A.A.A. Abdel Hafeez and M.S.A. Ewees* \\ Soils and Water Dept., Fac. of Agric., El-Fayoum University, Egypt
}

\begin{abstract}
GRICULTURAL utilization of desert marginal soils at El Fayoum Governorate edges is of importance to support the local farmer's incomes, particularly under the best and suitable management practices of land and available water resources. A newly reclaimed soil encompassing by Eocene limestone at the eastern edge of Tamia District was a matter of concern in this work. It is a sandy clay loam in texture, moderately saline, non-sodic, and calcareous in nature with a subsurface diagnostic horizon of calcigypsic one, and classified as Typic Calcigypsids, fine loamy, mixed, heperthermic, moderately deep. According to a parametric system, it could be evaluated as moderately suitable ( 2 ws $1 \mathrm{~s} 2 \mathrm{~s} 3 \mathrm{n}$ ), with soil limitations of wetness, soil depth, salinity/alkalinity and $\mathrm{CaCO}_{3}$ content, with an intensity degree for each, lies in the range of slight to moderate (rating $=90-80$ ).
\end{abstract}

The soils of this area are generally suffering from a very low productivity,which may be due to their high contents of $\mathrm{CaCO}_{3}$, low organic matter as well as a relatively high soil $\mathrm{pH}$ and soluble salts that might be reflected on nutrients availability and soil physical and chemical properties. Therefore, a field experiment was conducted on a newly reclaimed soil at the area of study during the two successive cultivation seasons of 2010-2011 and 2011-2012 using tomato plants (Lycopersicon esculentum, c.v. 1077 hybrid) as test crop. Plots were distributed in a randomized complete blocks with three replicates and irrigated with the only available source in the area (mixture of the Nile water and drainage water at a ratio of 1:1). Treatments applied were planned in an attempt to improve soil properties with a minimat risk of chemical pollution as follows : vermicompost (cattle manure added to earthworms) as an organic manure was applied to the soil plots at four rates $\left(0,10,15\right.$ and $\left.20 \mathrm{~m}^{3} \mathrm{fed}^{-1}\right)$ and elemental sulphur (i.e., agrochemical soil amendment) at four rates (i.e., 0, 50, 150 and $250 \mathrm{~kg} \mathrm{~S} f e d^{-1}$ ), while the rates of ascorbic acid were 0,150 and $300 \mathrm{mgL}^{-1}$, in form of few drops of Tween-20 added to the spraying solution as a surfactant.

Data showed considerable responses for either vermicompost, elemental sulphur or ascorbic acid especially at their highest rates $\left(20 \mathrm{~m}^{3}\right.$ vermicompost/feddan $+250 \mathrm{~kg}$ sulphur /feddan $+300 \mathrm{mg} \mathrm{L}^{-1}$ ascorbic acid/feddan) together; showed their positive response on the vegetative growth and flowering parameters of tomato plants, i.e., plant height, number of leaves/ plant, thickness of stem/plant at soil surface, number of branches/plant, leaf area, number of inflorescences/plant, number of flowers/inflorescence, dry weight/plant, and chlorophyll a \& b contents. Data also, showed great increases in essential nutrients uptake by tomato plants such as N, P, K, Fe, Mn and Zn due to the role of vermicompost in improving: a) Soil hydrophysical and chemical properties, b) Released organic constituents of active groups such as fulvic and humic acids which have the ability to retain the essential plant nutrients in available chelate forms) and c) Soil biological conditions enhancing mineralization of the released organic nutrients in available forms. On the other hand, it could be deduced that application of $\mathrm{S}$ as a soil amendment at a rate of $250 \mathrm{~kg} / \mathrm{fed}$ is important to sustain soil productivity and to obtain economically best crop yield attributes under such a calcareous soil for avoiding direct restrictive effect of $\mathrm{CaCO}_{3}$ on the nutrients released and their mobility towards plant roots.

Keywords: Calcareous soil, Limitations of soil productivity, Ascorbic acid, Elemental sulphur, Vermicompost and Tomato plants.

Correspondin author e mail: ee.omran@gmail.com

DOI : $10.21608 /$ ejss.2018.11808

C2018 National Information and Documentation Center (NIDOC) 
The newly reclaimed desert soils of El Fayoum region, Egypt and their sustainable techniques for agricultural utilization have become urgent and essential to overcome food security demands of the nation. In this accord, the scope of soil reclamation implies the use of both induction and deduction, particularly when limited land resources have to be allocated to alternative means and areas. So, the national agricultural policy of the local government stressed the importance of maximizing soil productivity by providing grown plants with their nutritional requirements without having undesirable impact on the environment as well as the problem of chemical residues in the export market commodities. To fulfill this aim, an assessment of relative soil potentiality is a must, especially under the adverse conditions of salinity stress, however, a general reduction in plant growth and yield due to salinity stress is widely documented (El Saidi, 1997).

Also, soil survey data of the newly reclaimed soils at the desert areas, especially those calcareous in nature, pointed to a considerable decrease in their productivity. This is mainly due to high $\mathrm{CaCO}_{3}$ content and low organic matter content, which represented the main factors for widespread occurrence of essential plant nutrients deficiency, particularly phosphorus and some micronutrients for grown crops (Takker and Walker, 1993). Also, high levels of soil $\mathrm{pH}$ due to the occurrence of high $\mathrm{CaCO}_{3}$ content and low organic matter exert negative influence on the availability of these micronutrients (Basyouny, 2005).

The use of organic manure as a soil amendment (i.e., Vermicomposting) to avail suitable environments for planting the newly reclaimed desert soils under the severe conditions of the Egyptian desert, i.e., the limited water resources, the inadequate moisture retention and the low fertility of the soils has become an accepted practice. Such supper absorbent material is associated quickly with irrigation water to form a gel, and in turn increases soil capacity to retain more pronounced water content. Water retained in this way is available to plants for some considerable time as required, in addition to it leads to alleviate the effect of salinity stress may be due to reduce the osmotic potential. Both chemical and biological properties of the conditioned soil are also improved. Moreover, nutrients uptake, water and fertilizers use efficiency by plants are beneficially increased, consequently plant growth and yield tendency to increase (El Hady et al., 2003).

Egypt. J. Soil Sci. 58, No.2 (2018)
Vermicomposting is the digestion of organic materials by earthworms (Eisenia fetida) which produce excreta known as casts. Edwards (1995) reported that in a Rothamsted study with 25 types of vegetables, fruits or ornamentals, earthworm casts (EW) performed better than compost or commercial potting mixture amendments. It was suggested that the higher crop performance of the cast treatment was due to: better soil physical structure; presence of plant growth hormones; higher levels of soil enzymes; and greater microbial populations. The beneficial effects of earthworm cast utilization in other horticulture settings have also been reported (Tomati et al., 1987, Hidalgo, 1999 and Saciragic \& Dzelilovic, 1986 ).

Earthworm cast amendment has been shown to increase plant dry weight (Edwards, 1995 and Lui et al., 1991) and plant $\mathrm{N}$ uptake (Tomati et al., 1994). The beneficial effect of EW has been observed in both horticultural plants ( Tomati et al., 1987, Hidalgo, 1999 and Saciragic \& Dzelilovic, 1986 ) and in agronomic crops (Pashanasi et al., 1996).

Many authors such as El-Foly (2004) mentioned that the organic manures fertilizers are very important for providing the plants with their nutritional requirements without having undesirable impact on the environment. For many years, organic fertilizers have been used basically as a mean of alleviation of the problem of chemical residues in the export market commodities.

Moreover, Foyer and Halliwell (1976) reported that ascorbic acid is an important antioxidant defense in plant cells (to protect them by scavenging the reactive oxygen species ascorbic acid proved to be enhancing substance for cell divisions and protects plant cells against free radicals which are responsible for plant senescence, besides its effect on countracting drought, salinity and diseases stresses as well as its auxinic action consequently, enhancing growth characters (Elade, 1992). It also stimulates respiration activities, cell division and many enzymes activities (Rautenkranz et al., 1994). In this respect, AL-Qubaie (2002) stated that ascorbic acid has an auxinic action and synergistic that effect on the biosynthesis of carbohydrate and controlling the incidence of most fungi on plants which making them in vigorous states and positively reflects on plant yield. Besides, the induced effect of ascorbic acid on oil\% may be due to that vitamin is recognized to be coenzyme 
involved in specific biochemical reactions in plants such as oxidative and non-oxidative decarboxylations. The widespread uses of these natural and safety substances (i.e., antioxidants of ascorbic acid) for enhancing growth and productively of many crops are confirmed the aforementioned scientific opinions. Since ascorbic acid has synergistic effect on growth, flowering, yield and chemical composition under favourable and unfavourable environmental conditions, i.e., salinity (Ali, 2002 on tomato plants and Rady, 2006 on sunflowers plants).

Tomato (Lycopersicon esculentum, c.v. 1077 hybrid) is one of the important widespread crops in the world, and is considered moderately sensitive to salt stress, since it can tolerate a pronounced salinity level. However, salt tolerance of tomato plants increased when the application of salinity was delayed, and fruit quality could be improved, while yield was not significantly reduced when $4 \mathrm{dS} / \mathrm{m}$ saline water was applied 16 days after transplanting (Shuqin et al., 2007).

Many studies were carried out to investigate the beneficial effects of some materials as soil amendments, such as elemental sulphur, Ahmed (2009) reported that sulphur fertilization significantly affected plant height, chlorophyll and number of green leaves/plant, which implies a better photosynthetic activity in comparison with plants grown without S. They found also that the blending of elemental sulphur with urea slowed down its transformation and reduced volatilization of $\mathrm{NH}_{3}$ to $20 \%$ of urea-N. Awad et al. (2000), Mostafa (2000) and Negm et al. (2002 a \& b) clearified the importance of sulphur mixed with some organic wastes for improving the properties of calcareous soil and its productivity of grown plants due to increasing the efficiency of nutrients availability and mobility.

Technical choices of applying sulphur rates in combination with organic manures through enough periods may be one of the most important investigations in the newly reclaimed calcareous soils of Egypt. The beneficial effects could be achieved through improving some soil physical and chemical properties, i.e., soil water stable aggregates, permeability, available moisture retention, bulk density, organic matter, soil $\mathrm{pH}$ and available nutrient contents. These favourable conditions are actually reflected on increasing use efficiency of water and nutrients uptake by plant, consequently leads to increase the vegetative growth and crop production (Awadalla et al., 2003 and Fathi et al., 2005).
Accordingly, the present work was planned for studying the effect of different rates of vermicomposting (organic manure), elemental sulphur (agrochemical soil amendment) and exogenous application of ascorbic acid on growth parameters, yield and some chemical constituents of tomato plants (Lycopersicon esculentum, c.v. 1077 hybrid), grown under a salinity calcareous reclaimed soils at El Fayoum Governorate during both 2010/2011 and 2011/2012 cultivation seasons. Using tomato as an indicator plant is considered one of the most important crops growing in such governorate for local consumption and exportation.

\section{Materials and Methods}

\section{Materials}

The current work was executed on a newly reclaimed saline calcareous soil at the eastern rim of Tamia District, Fayoum Governorate. Some physical and chemical characteristics of the studied soil as profile mean values are given in Table 1 .

\section{Experimental work}

A field experiment was conducted on the chosen soil site, where tomato seeds (Lycopersicon esculentum, cv. 1077 hybrid) were sown in the nursery on July 9, 2010 and July 6, 2011. Thirty days after seed sowing seedlings were transplanted to the experimental field. The experimental plot was $480 \mathrm{~m}^{2}$, each plot was planned to include 20 rows $(20 \mathrm{~m}$ long and 1.20 $\mathrm{m}$ width), and the interplant spacings were 50 $\mathrm{cm}$ within each row (about 11000 plants/fed). The investigated soil plots were irrigated with available irrigation water source (mixture of the Nile water and drainage water at a ratio of $1: 1$ ) in randomized complete block design, with three replicates. Chemical analysis of irrigation water source were done according to Black et al. (1965) and presented in Table 2. The agricultural management practices were conducted as usual, where vermicompost (cattle manure added to earthworms) as an organic manure was applied to plots at four rates $\left(0,10,15\right.$ and $\left.20 \mathrm{~m}^{3} \mathrm{fed}^{-1}\right)$ and elemental sulphur (i.e., agrochemical soil amendment) was added to the soil plots at four rates

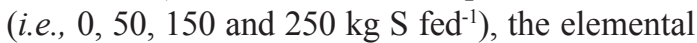
sulphur and vermicompost were thoroughly mixed with soil at the depth $(0-25 \mathrm{~cm})$ during soil preparation processes. Ascorbic acid was foliar sprayed at three rates 0,150 and $300 \mathrm{mgL}^{-1}$, after 
40 and 65 days from transplanting. Few drops of Tween-20 added to the spraying solution as a surfactant. both vermicompost, ascorbic acid and sulphur were added either solely or in combined treatments. The main chemical characteristics and nutrients status of the applied vermicompost (dry weight basis) were also determined according to the procedures described by Black et al. (1965) Soltanpour \& Schwab (1977) and Page et al.
(1982), and the obtained data are presented in Table 3

The applied fertilizers were added as ammonium nitrate $(33.5 \% \mathrm{~N})$, superphosphate $\left(15 \% \mathrm{P}_{2} \mathrm{O}_{5}\right)$ and potassium sulfate $\left(48 \% \mathrm{~K}_{2} \mathrm{O}\right)$, at the rates of $100 \mathrm{~kg} \mathrm{~N}, 40 \mathrm{~kg} \mathrm{P}_{2} \mathrm{O}_{5}$ and $48 \mathrm{~kg}$ $\mathrm{K}_{2} \mathrm{O}$ / fed. $\mathrm{P}$ and $\mathrm{K}$ fertilizers were entirely added at transplanting, while $\mathrm{N}$ was applied in two equal doses ( 28 and 56 days after transplanting).

TABLE 1. Some physical and chemical properties of the experimental soil (as profile mean values)

\begin{tabular}{|c|c|c|c|}
\hline Soil characteristics & Value & Soil characteristics & Value \\
\hline Particle size distribution \%: & & Soluble cations (soil paste, $m$ molcL ${ }^{-1}$ ): & \\
\hline Sand & 48.83 & $\mathrm{Ca}^{2+}$ & 28.70 \\
\hline Silt & 23.65 & $\mathrm{Mg}^{2+}$ & 13.10 \\
\hline Clay & 27.52 & $\mathrm{Na}^{+}$ & 36.20 \\
\hline Textural class & SCL* & $\mathrm{K}^{+}$ & 0.93 \\
\hline Soil chemical properties: & & Soluble anoions (soil paste, $m$ molcL ${ }^{-1}$ ): & \\
\hline Soil pH (1.25 soil water suspension) & 8.32 & $\mathrm{CO}_{3}^{2-}$ & 0.00 \\
\hline $\mathrm{CaCO}_{3} \%$ & 24.90 & $\mathrm{HCO}_{3}^{-}$ & 3.50 \\
\hline Gypsum \% & 5.67 & $\mathrm{Cl}^{-}$ & 46.50 \\
\hline Organic matter $\%$ & 0.48 & $\mathrm{SO}_{4}^{2-}$ & 28.93 \\
\hline $\mathrm{ECe}(\mathrm{dS} / \mathrm{m}$, soil paste extract) & 7.95 & ESP & 7.46 \\
\hline Available macronutrients (mgkg-1 & & - DTPA-extractable micronutrients (mgkg ${ }^{-1}$ ): & \\
\hline $\mathrm{N}$ & 34.97 & $\mathrm{Fe}$ & 4.30 \\
\hline $\mathrm{P}$ & 4.71 & $\mathrm{Mn}$ & 0.75 \\
\hline K & 324.50 & $\mathrm{Zn}$ & 0.72 \\
\hline
\end{tabular}

TABLE 2. Water characteristics of the used irrigation water

\begin{tabular}{|c|c|}
\hline Water characteristics & Value \\
\hline Water $\mathrm{pH}$ & 7.32 \\
\hline $\operatorname{ECiw}\left(\mathrm{dSm}^{-1}\right)$ & 1.35 \\
\hline Total dissolved salts $\left(\mathrm{mgL}^{-1}\right)$ & 864.00 \\
\hline \multicolumn{2}{|l|}{ Soluble ions (m molc L-1): } \\
\hline $\mathrm{Ca}^{++}$ & 2.13 \\
\hline $\mathrm{Mg}^{++}$ & 1.92 \\
\hline $\mathrm{Na}^{+}$ & 9.25 \\
\hline $\mathrm{K}^{+}$ & 0.60 \\
\hline $\mathrm{CO}_{3}^{--}$ & 0.00 \\
\hline $\mathrm{HCO}_{3-}$ & 5.03 \\
\hline $\mathrm{Cl}^{-}$ & 6.72 \\
\hline $\mathrm{SO}_{4}^{--}$ & 2.15 \\
\hline Sodium adsorption ratio $\quad$ (SAR) & 6.50 \\
\hline Residual sodium carbonate (RSC) & 0.98 \\
\hline *Irrigation water suitability degree & $\mathrm{C} 2 \mathrm{~S} 2$ \\
\hline
\end{tabular}

*According to the water salinity and sodicity classes undertaken by Ayers and Westcot (1985)

Egypt. J. Soil Sci. 58, No.2 (2018) 
TABLE 3 . The main chemical characteristics of applied vermicompost (dry weight basis)

\begin{tabular}{|c|c|c|c|c|c|c|}
\hline \multicolumn{4}{|c|}{ Character } & \multicolumn{3}{|c|}{ Value } \\
\hline Weight $\mathrm{o}$ & $\mathrm{kg})$ & & \multicolumn{4}{|c|}{798.45} \\
\hline $\mathrm{pH}(1: 10$ & uspen & & \multicolumn{4}{|c|}{7.22} \\
\hline Moisture & & & \multicolumn{4}{|c|}{8.35} \\
\hline $\mathrm{EC}(\mathrm{dS} / \mathrm{n}$ & water & & \multirow{2}{*}{\multicolumn{4}{|c|}{1.79}} \\
\hline Organic $\mathrm{r}$ & & & \multirow{2}{*}{\multicolumn{4}{|c|}{34.75}} \\
\hline Organic c & & & & & & \\
\hline $\mathrm{C} / \mathrm{N}$ ratio & & & \multicolumn{4}{|c|}{12.02} \\
\hline \multicolumn{7}{|c|}{ Total macro and micronutrients \% } \\
\hline $\mathrm{N}$ & $\mathrm{P}$ & K & $\mathrm{Fe}$ & $\mathrm{Mn}$ & $\mathrm{Zn}$ & $\mathrm{Cu}$ \\
\hline 1.68 & 1.02 & 2.53 & 1.33 & 0.2328 & 0.1296 & 0.1274 \\
\hline \multicolumn{7}{|c|}{ Available macro and micronutrients ( $\mathrm{mg} \mathrm{kg}^{-1}$ ) } \\
\hline $\mathrm{N}$ & $\mathrm{P}$ & K & $\mathrm{Fe}$ & $\mathrm{Mn}$ & $\mathrm{Zn}$ & $\mathrm{Cu}$ \\
\hline 768 & 273 & 587 & 194 & 72 & 51 & 35 \\
\hline
\end{tabular}

c. Data of tomato plant parameters recorded:

1. Vegetative growth and flowering characters : 60 days after transplanting, random samples consisted of eight plants was taken from each experimental plot to determine some growth and flowering parameters, i.e., plant height, number of leaves/plant, thickness of stem/plant at soil surface, number of branches/plant, leaf area, number of inflorescences/plant, number of flowers/inflorescence, dry weight/plant, and the chlorophyll a \& b contents (Hiscox and Isrealstam, 1979).

2. Yield potential: Fruit from nine plants were collected from each experimental plot in the ripening stage to determine yield and its components, i.e., number of fruit/plant, and fruit yield/plant. The total yield was determined as the total weight of the harvested fruit through the whole harvesting period excluding the damaged.

3. Chemical analysis: Leaves were taken from the fourth upper of tomato stem of eight randomly collected plants after 90 days from transplanting, washed with distilled water, dried with paper towels, then dried at $70{ }^{\circ} \mathrm{C}$ and wet digested (Van Schouwenberg, 1968) for the determination of N, P (A.O.A.C., 1990), K, Na (Wilde et al., 1985) and $\mathrm{Cl}$ (Higinbotham et al., 1967).

4. Fruit samples: These samples were taken from the $3^{\text {rd }}$ harvest at red ripe stage from each experimental plot to determine fruit quality parameters, i.e., average weight of fruit, firmness using fruit pressure tester with a probe diameter of $0.8 \mathrm{~cm}$ and values were expressed in pounds, total soluble solids (TSS) using hand held Brix meter, titratable acidity, vitamin $C$ and total sugar) as described by A.O.A.C. (1990).

\section{d. Statistical analysis:}

The obtained data of plant parameters were subjected to the statistical analysis, where the least significant difference test (L.S.D.) at 0.05 level was used to verify the differences between treatments according to Snedccor and Cochran (1980).

\section{Results and Discussion}

The soil site under consideration is mainly encompassing the eastern desert rim of $\mathrm{El}$ Fayoum Depression and developed on the Eocene limestone, as the source of soil parent materials, under climatic conditions of long hot rainless summer and short mild winter.

On basis of soil properties and the concentrations of available nutrients and according to the deficiency and sufficiency limits given by (Lindsay \& Norvell, 1978 and Page et al., 1982), soil organic matter content is relatively low, may be due to the mineral nature of soil deposits and the prevailing hot and arid climatic conditions. Values of $\mathrm{pH}$ and ESP (i.e., $<8.5$ and $<$ 15 , respectively), value of soil ECe (i.e., $>4 \mathrm{dS} / \mathrm{m}$ ), could be classified as moderately saline and nonsodic soil. The recorded available contents of $\mathrm{N}, \mathrm{P}$, $\mathrm{Mn}$ and $\mathrm{Zn}$, in general, lie at the low levels, with exception of $\mathrm{K}$ and $\mathrm{Fe}$ contents which lie at the high and medium levels, respectively.

Egypt. J. Soil Sci. 58, No. 2 (2018) 


\section{Soil taxonomy and evaluation}

Taxonomic unit of the current experimental soil is identified and named according to the results of soil morphological and physio-chemical characteristics at the family level according to Soil Survey Staff (1999) as Typic Calcigypsids, fine loamy, mixed, hyperthermic and moderately deep. Also, according to a parametric system undertaken by Sys and Verheye (1978), the intensity degrees of soil limitations and suitability categories for the studied soil were estimated the soil texture, wetness, soil depth, salinity/alkalinity and $\mathrm{CaCO}_{3}$ content are the most effective limitations for soil productivity.

The relative high $\mathrm{CaCO}_{3}$ content is also one of the more effective limitation for soil productivity, due to its restrictive effect on nutrients availability and mobility towards plant roots and in turn their uptake.

\section{Effect of treatments on nutrients availability}

Data presented in Tables 4 and 5 show that the beneficial effect of the applied treatments of organic matter (vermicompost) and elemental sulphur as solely or combined was commonly achieved by lowering soil $\mathrm{pH}$, and in turn encouraging the availability of plant essential nutrients, especially phosphorus and micronutrients may be as a result of forming organo-metalic compounds of chelate metals of micronutrients(Fe, Mn and $\mathrm{Zn}$ ). This could be an effective practice of nutrient management by reducing inorganic rate or nutrient losses. These results are in agreement with those obtained by many investigators on different field crops, such as Abou Zied et al. (2005), Basyouny (2005) and Ashmaye et al. (2008). With regard to the interactive effect of applied poultry manure and ascorbic acid, results again revealed a trend of slightly increases, but without significant differences. It is evident also that the amounts of available nutrients in the soil differed according to the soil type, plant physiological stage and their contents in the applied organic manure, which are more related to its natural source. Furthermore, the treated soil with organic manure resulted in more released of active organic acids, which are responsible for most of nutrients availability in soil. This result is in harmony with Hala et al. (2002) showed that vermicomposting is good supplemental sources of readily available $\mathrm{P}$ and $\mathrm{K}$, as well as for $\mathrm{N}$.

The superiority of combined effects of applied organic matter elemental sulphur and ascorbic acid treatments for the noticeable reduction in the values of soil $\mathrm{pH}$ and ECe and vs a pronounced increase in soil available nutrient contents and biological conditions that enhancing nutrients uptake by plants could be interpreted as follows:

TABLE 4. Effects of applied vermicompost, elemental sulphur and ascorbic acid on the concentration of some soil available macro-nutrients contents (the average of the two successive growing seasons)

\begin{tabular}{|c|c|c|c|c|c|c|c|c|c|c|}
\hline \multirow{4}{*}{$\begin{array}{c}\text { Vermicompost } \\
\mathbf{m}^{3} / \text { fed. }\end{array}$} & Applied-S & \multicolumn{9}{|c|}{ Concentration of soil macronutrients (mg/kg soil) } \\
\hline & & \multicolumn{3}{|c|}{$\mathbf{N}$} & \multicolumn{3}{|c|}{$\mathbf{P}$} & \multicolumn{3}{|c|}{$\mathbf{K}$} \\
\hline & & & & & rbic : & $\mathrm{d}\left(\mathrm{mgL}^{-}\right.$ & & & & \\
\hline & & 0 & 150 & 300 & 0 & 150 & 300 & 0 & 150 & 300 \\
\hline \multirow{6}{*}{0} & 0 & 40.45 & 40.80 & 40.93 & 3.92 & 3.98 & 4.07 & 278.17 & 278.87 & 278.88 \\
\hline & 50 & 42.35 & 42.95 & 43.21 & 4.13 & 4.40 & 4.65 & 285.36 & 286.48 & 287.49 \\
\hline & 150 & 45.70 & 46.40 & 46.67 & 4.24 & 4.63 & 4.95 & 291.53 & 294.89 & 292.62 \\
\hline & 250 & 48.25 & 49.26 & 49.36 & 5.02 & 5.51 & 5.95 & 299.17 & 302.41 & 301.85 \\
\hline & 0 & 45.75 & 46.16 & 46.35 & 4.96 & 5.55 & 5.70 & 322.53 & 323.49 & 323.08 \\
\hline & 50 & 49.08 & 49.83 & 50.01 & 5.07 & 5.78 & 6.00 & 346.77 & 347.93 & 348.28 \\
\hline \multirow{4}{*}{10} & 150 & 55.25 & 56.20 & 57.35 & 5.15 & 6.05 & 6.10 & 364.80 & 366.91 & 367.38 \\
\hline & 250 & 62.85 & 63.93 & 64.09 & 6.22 & 7.29 & 7.38 & 384.12 & 386.54 & 387.06 \\
\hline & 0 & 52.34 & 52.86 & 53.09 & 5.70 & 6.57 & 6.92 & 342.75 & 344.56 & 345.06 \\
\hline & 50 & 58.70 & 59.60 & 59.80 & 6.17 & 7.07 & 7.31 & 357.92 & 358.62 & 360.51 \\
\hline \multirow{3}{*}{15} & 150 & 64.10 & 65.11 & 65.45 & 8.35 & 9.39 & 8.51 & 375.43 & 376.95 & 378.22 \\
\hline & 250 & 70.15 & 71.28 & 71.50 & 8.10 & 9.19 & 9.40 & 404.19 & 405.97 & 406.59 \\
\hline & 0 & 59.12 & 59.75 & 60.05 & 7.28 & 8.06 & 8.27 & 361.05 & 362.94 & 363.88 \\
\hline \multirow{7}{*}{20} & 50 & 65.97 & 66.95 & 67.20 & 7.80 & 8.89 & 9.02 & 376.04 & 377.12 & 378.71 \\
\hline & 150 & 70.14 & 71.27 & 71.60 & 8.20 & 9.36 & 9.57 & 406.79 & 408.21 & 409.15 \\
\hline & 250 & 77.45 & 78.68 & 79.02 & 9.55 & 10.80 & 11.01 & 431.55 & 433.57 & 434.85 \\
\hline & $\mathrm{OM}$ & & 0.0577 & & & 0.0300 & & & 0.4468 & \\
\hline & $\mathrm{S}$ & & 0.0486 & & & 0.0266 & & & 0.3440 & \\
\hline & AC & & 0.0973 & & & 0.0533 & & & 0.6880 & \\
\hline & $\mathrm{OM} * \mathrm{~S}$ & & 0.0819 & & & 0.0425 & & & 0.4483 & \\
\hline \multirow{3}{*}{ L.S.D. at 0.05} & $\mathrm{OM}^{*} \mathrm{AC}$ & & N.S & & & N.S & & & N.S & \\
\hline & $\mathrm{S}^{*} \mathrm{AC}$ & & N.S & & & N.S & & & N.S & \\
\hline & $\mathrm{OM} * \mathrm{~S} * \mathrm{AC}$ & & N.S & & & N.S & & & N.S & \\
\hline
\end{tabular}

Egypt. J. Soil Sci. 58, No.2 (2018) 
TABLE 5. Effects of applied vermicompost, elemental sulphur and ascorbic acid on the concentration of available micro-nutrient contents (the average of the two successive growing seasons)

\begin{tabular}{|c|c|c|c|c|c|c|c|c|c|c|}
\hline \multirow{4}{*}{$\begin{array}{c}\text { Vermicompost } \\
\mathbf{m}^{3} / \text { fed. }\end{array}$} & \multirow{4}{*}{$\begin{array}{c}\begin{array}{c}\text { Applied-S } \\
\text { (kg/fed) }\end{array} \\
\\
0\end{array}$} & \multicolumn{9}{|c|}{ Concentration of soil micronutrients (mg/kg soil) } \\
\hline & & \multirow{2}{*}{\multicolumn{2}{|c|}{$\mathbf{F e}$}} & \multirow{2}{*}{\multicolumn{3}{|c|}{$\begin{array}{c}\text { Mn } \\
\text { Ascorbic acid (mgL }\end{array}$}} & & \multicolumn{3}{|c|}{$\mathbf{Z n}$} \\
\hline & & & & & & & & & & \\
\hline & & 0 & 150 & 300 & 0 & 150 & 300 & 0 & 150 & 300 \\
\hline \multirow{4}{*}{0} & & 5.04 & 5.11 & 5.15 & 1.98 & 2.00 & 2.01 & 0.76 & 0.77 & 0.78 \\
\hline & 50 & 5.32 & 5.44 & 5.48 & 2.05 & 2.10 & 2.13 & 0.80 & 0.82 & 0.83 \\
\hline & 150 & 5.39 & 5.57 & 5.62 & 2.11 & 2.20 & 2.24 & 0.85 & 0.87 & 0.89 \\
\hline & 250 & 6.20 & 6.42 & 6.48 & 2.23 & 2.35 & 2.38 & 0.92 & 0.95 & 0.0 .96 \\
\hline \multirow{3}{*}{10} & 0 & & 5.46 & & 3.01 & 3.06 & 3.09 & 0.91 & 0.94 & 0.96 \\
\hline & 50 & $\begin{array}{l}5.31 \\
6.26\end{array}$ & $\begin{array}{l}5.40 \\
6.44\end{array}$ & $\begin{array}{l}5.53 \\
6.50\end{array}$ & 3.24 & 3.33 & 3.37 & 0.96 & 1.02 & 105 \\
\hline & 150 & 7.05 & 7.30 & 7.45 & 3.39 & 3.51 & 3.55 & 1.03 & $\begin{array}{l}1.02 \\
1.11\end{array}$ & 1.14 \\
\hline \multirow{4}{*}{15} & 250 & 7.30 & 7.60 & 7.78 & 3.55 & 3.60 & 3.76 & 1.09 & 1.21 & 1.25 \\
\hline & 0 & 5.70 & 5.89 & 5.96 & 3.59 & 3.68 & 3.70 & 1.23 & 1.30 & 1.33 \\
\hline & 50 & 6.65 & 6.92 & 7.00 & 3.66 & 3.79 & 3.83 & 1.29 & 1.39 & 1.42 \\
\hline & 150 & 7.25 & 7.59 & 7.67 & 3.72 & 3.88 & 3.93 & 1.34 & 1.45 & 1.51 \\
\hline \multirow{6}{*}{20} & 250 & 8.00 & 8.41 & 8.52 & 3.95 & 4.14 & 4.18 & 1.43 & 1.58 & 1.62 \\
\hline & 0 & $\begin{array}{l}0.00 \\
6.15\end{array}$ & 6.41 & 6.50 & 3.95 & 4.07 & 4.11 & 1.56 & 1.66 & 1.69 \\
\hline & 50 & 7.45 & 7.79 & 7.94 & 4.07 & 4.24 & 4.27 & 1.61 & 1.75 & 1.77 \\
\hline & 150 & 7.90 & 8.35 & 8.54 & 4.20 & 4.39 & 4.43 & 1.67 & 1.84 & 1.87 \\
\hline & 250 & 872 & 9.28 & 952 & 4.64 & 4.88 & 4.93 & 1.78 & 1.99 & 2.02 \\
\hline & $\mathrm{OM}$ & & 0.0173 & & & 0.0100 & & & 0.0058 & \\
\hline \multirow{5}{*}{ L.S.D. at 0.05} & $\mathrm{~S}$ & & 0.0138 & & & 0.0049 & & & 0.0015 & \\
\hline & $\mathrm{AC}$ & & 0.0275 & & & 0.0097 & & & 0.0031 & \\
\hline & $\mathrm{OM}^{*} \mathrm{~S}$ & & 0.0116 & & & 0.0041 & & & 0.0039 & \\
\hline & $\mathrm{OM}^{*} \mathrm{AC}$ & & N.S & & & N.S & & & N.S & \\
\hline & $\mathrm{OM} * \mathrm{~S} * \mathrm{AC}$ & & N.S & & & N.S & & & N.S & \\
\hline
\end{tabular}

i. The integrated role of applied vermicomposting plus elemental sulphur were more pronounced for nutrients availability in the soil, may be the released active organic acids during microbial activity that enhancing the solubilization of nutrient from the native and added sources. Such prevailing conditions enhancing the slow release of nutrients during the decomposition and mineralization processes as well as minimizing their possible lose by leaching throughout the studied relatively coarse texture soil (Mohammed, 2004).

ii. The application of vermicomposting plus elemental sulphur tends to accelerate, due to soil microbial activity, the released active organic and inorganic acids $\left(\mathrm{H}_{2} \mathrm{SO}_{4}\right)$ that led to decrease soil $\mathrm{pH}$ as well as they have used to chelate metals of Fe, $\mathrm{Mn}, \mathrm{Zn}$ and $\mathrm{Cu}$. These chelated metal cations are not sensitive to the restriction or the adverseable effects of alkaline side, consequently they are found as strategic storehouse in organo-metalic compounds that are more suitable for uptake by plant roots.

The aforementioned results are in agreement with Kaplan et al. (2005) who reported that a potential strategy to enhance nutrients availability is the lowering soil $\mathrm{pH}$, this can be achieved through application of acid-producing fertilizers like sulphur-containing material.

Regarding composted the beneficial effect of applied vermicompost, data given in Tables 3, 5 and 6) denote that it is mainly attributed to its high contents of essential macro and micronutrients, beside its beneficial effects on soil physicochemical properties through lowering soil $\mathrm{pH}$ and maintaining a suitable air-moisture regime. These favourable condition leads to enhance the microbial activity in soil, which accelerate the decomposition of organic matter and maximize soil content of nutrients. These findings agree with those of Sarker et al. (1992) who found that, the organic manure provided a substantial modification of physical properties, especially soil aeration which affected solubility, adsorption and availability of nutrients.

Egypt. J. Soil Sci. 58, No. 2 (2018) 


\section{Response of plant characters to applied treatments \\ a. Vegetative growth and flowering parameters}

Vegetative growth and flowering parameters of tomato plants, i.e., plant height, number of leaves/plant, thickness of stem/plant at soil surface, number of branches/plant, leaf area, number of inflorescences/plant, number of flowers/inflorescence, dry weight/plant, and the chlorophyll a \& b contents were greatly affected by the application of vermicompost, elemental sulphur and ascorbic acid as solely or as combined treatments. However, these plant parameters exhibited relatively more response at the highest rates, as shown in Tables 6 and 7.

Since vegetative growth represents a part of the total biological yield of any crop, its parameters play an important determinant role of the economic yield. Data of the studied tomato growth parameters showed increases with applied treatments with a superiority towards the combined treatment of (vermicompost + elemental sulphur + ascorbic acid). It is evident that impact of the applied treatments of vermicompost on the dry matter productions was more attributed to the leaves area and number. The obtained increases in the total dry matter accumulations can be explained on basis of the fact that grater leaves area and number contributed to more photosynthesis and better carbohydrates yield. These findings are consistent with those obtained by Duncan (1971) who obviously cleared the importance of canopy structure in light interception, vegetative growth and yield.

In conformity with the obtained data recorded in Tables 6 and 7, the values of growth parameters under study substantially increased by increasing either applied vermicompost, elemental sulphur or ascorbic acid rates of $20 \mathrm{~m}^{3} \mathrm{fed}^{-1}, 250 \mathrm{~kg}$ $\mathrm{fed}^{-1}$ and $300 \mathrm{mg} \mathrm{L}^{-1}$, respectively. In addition, soil application of vermicompost and sulphur to tomato plants increased the availability of macro and micro nutrients (Tables 4 and 5), and this was reflected on nutrients uptake, plant growth and flowering parameters. These findings are in line with those of Cox (1993) who stated that vermicomposting resulted in greater plant biomass production due to a slower rate of nitrogen mineralization that was more synchronized with the plant requirements.

The mechanism of organic manure on stimulating growth may be similar to that of plant growth regulators as vermicomposting include auxins or function as auxins and thus affect plant metabolism in a positive manner. On the other hand, it is clear from the obtained results of this study that, application of vermicomposting to soil in combination with foliar spray with ascorbic acid and elemental sulphur produced plants having vigorous growth as a result of the enhancement of creation more number of leaves (Table 6), consequently encouragement of leaf photosynthetic pigments. Some photosynthates, among them osmotic solutes, total soluble sugar and the nutritional status (Tables 9-11) enable plants to overcoming the adverse conditions of the newly reclaimed soils. That was true, since these osmotic substances are important for sustenance cell turger that leading to maintenance of metabolic activities, among them the activity of antioxidant defense in plant cells. Thus, it could be recommended that ascorbic acid as a natural and safety antioxidant should be widespread uses, due to it has synergistic effect on growth, yield and its chemical composition under either favourable or unfavourable environmental conditions (Ali, 2002 and Rady, 2006). In this respect, Foyer and Halliwell (1976) and Elade (1992) reported that ascorbic acid is an important antioxidant to protect sustenance cell turger by scavenging the reactive oxygen species ascorbic acid. However, ascorbic acid proved to be enhancing substance for cell divisions and protects plant cells against free radicals, which are responsible for plant senescence, besides its effect on counteracting drought, salinity and diseases stresses as well as its auxinic action. It also stimulates respiration activities, cell division and many enzymes activities (Rautenkranz et al., 1994).

Chlorophyll a and b contents were significantly higher in plants amended with vermicomposting, elemental sulphur and ascorbic acid. This is testimony for the longer source activity of nutrients uptake by crop. This enhanced the current photosynthesis for developing vegetative growth parameters that leading to the development of dry matter production per plant. That was true, since the applied treatments led to an enrichment soil media in both organic and mineral substances essential to plant growth and activating the biochemical processes in plants, i.e., respiration, photosynthesis and chlorophyll content, which increased the pea green pod and green seed yields and their quantity parameters (Hegazi, 2004). 


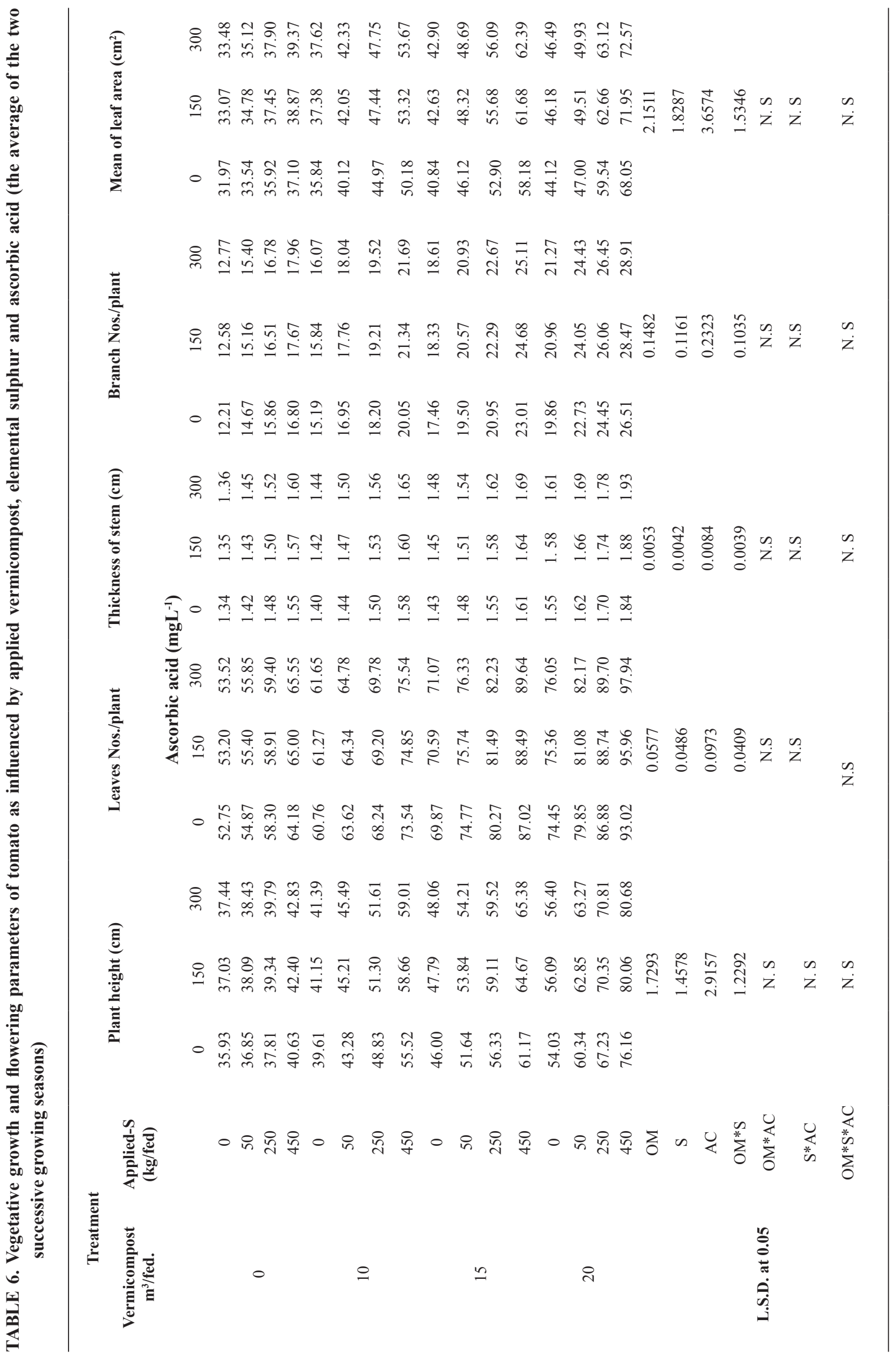

Egypt. J. Soil Sci. 58, No. 2 (2018) 


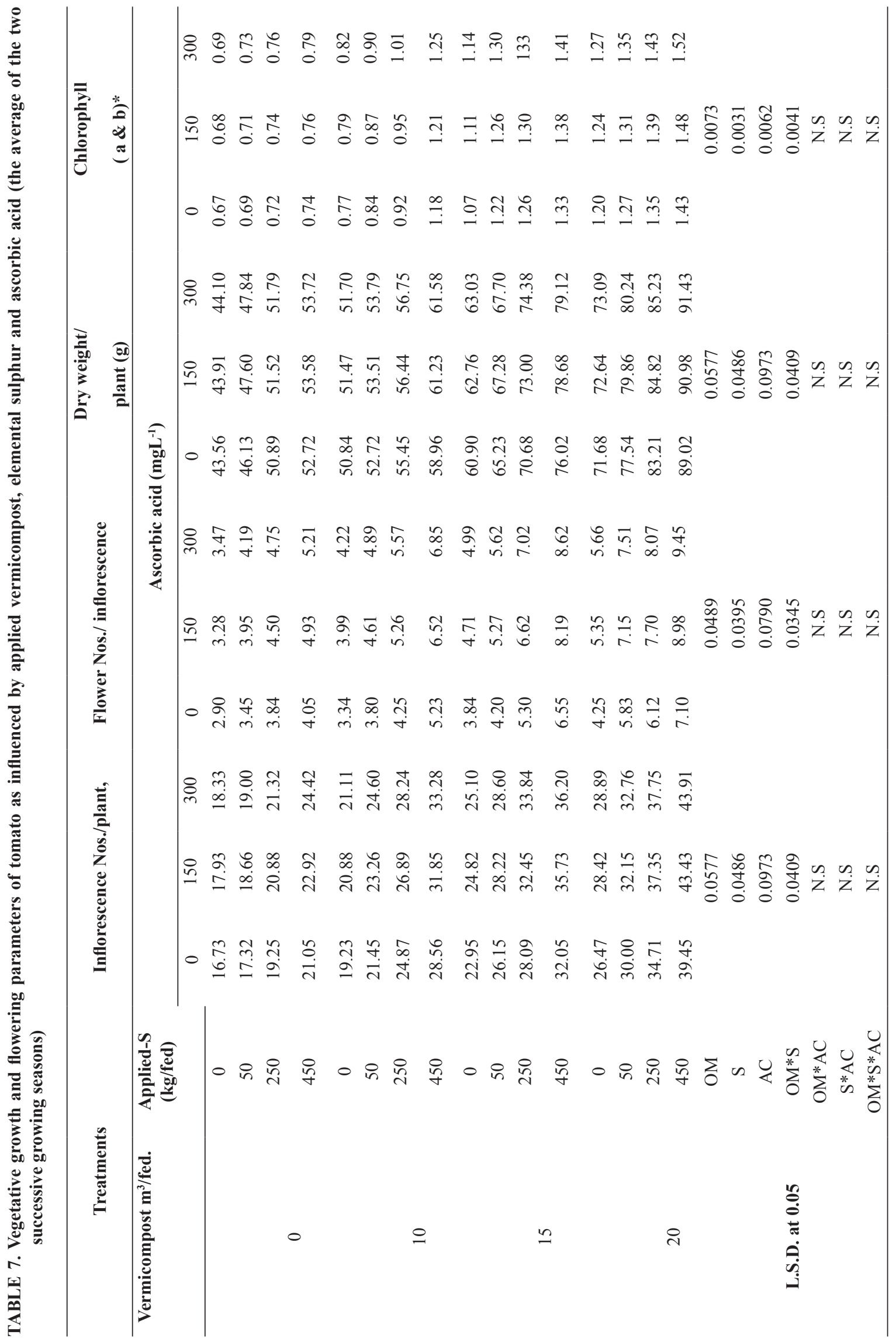

Egypt. J. Soil Sci. 58, No.2 (2018) 
In general, combine of the vermicomposting, elemental sulphur and ascorbic acid had a greatly positive effect on vegetative growth and flowering parameters of tomato plants as compared to the applied the previous materials alone. (Osman \& Ewees, 2008, Rady \& Migawer, 2010 and Rady, 2011).

\section{b. Tomato fruit yield and quality}

Data in Tables 8 and 9 reveal that there was a positive effective role of the applied vermicomposting, elemental sulphur and ascorbic acid on both tomato yield and its quality under the conditions studied experimental soil. Such relative increases could be attributed to significantly higher increments in dry weights and number of flowers per plant, which positively reflected on the higher number of tomato fruit and yield per plant and feddan. This was expected, since favourable conditions of soil properties was obtained as a result of applied vermicompost. The greatest values of tomato yield and its quality were associated with tomato plants received the vermicompost, elemental sulphur and ascorbic acid at the rates of $20 \mathrm{~m}^{3} \mathrm{fed}^{-1}, 250 \mathrm{~kg} \mathrm{fed}^{-1}$ and $300 \mathrm{mg} \mathrm{L}^{-1}$, respectively compared to the initial state of soil (control). On the contrary, the relatively low total yield of tomato was obtained by plants received the vermicompost, elemental sulphur and ascorbic acid at the rates of $10 \mathrm{~m}^{3}$ fed $^{-1}$, $50 \mathrm{~kg} \mathrm{fed}{ }^{-1}$ and $150 \mathrm{mg} \mathrm{L}^{-1}$, respectively .This is in harmony with the findings of Gomaa (1997) and McMullan et al. (1998) who pointed out that total yield was highly correlated with the development of vegetative growth as well as dry matter accumulation. The increase in total yield of tomato result by applied vermicompost may be more attributed to organic materials derived such as active organic acids, which enhances soil aggregation, soil aeration and increases water holding capacity as well as encouraging the availability, mobility and uptake of essential nutrients by growing plants, and in turn offers good environmental conditions for the root system of tomato plants (Abou El- Magd et al., 2005). In addition, the applied vermicompost is rich in essential nutrient contents that slow release nutrients all over the growth stages along the growing season. These beneficial conditions create better nutrients absorption and favorable the vegetative growth and development of root system, which may lead to increases in dry matter accumulation. Consequently, better total yield of tomato would be obtained by applying vermicomposting and the application of ascorbic acid at a suitable rate to alleviate the possible fears of chemical pollution for such vegetable crop and environmental risks. AL-Qubaie (2002) stated that ascorbic acid has an auxinic action and synergistic effect on the biosynthesis of carbohydrate and controlling the incidence of most fungi on plants which making them in vigorous states and positively reflects on crop yield.

Thus, the positive role of the combined treatments may be more attributed to efficiency of either nutrients released or uptake and enhancing dry matter yield, fruit yield and quality of tomato. These results are also in line with those obtained by Aly (2003) who stated that the pronounced bacterial activity, due to the applied organic and inorganic soil amendments are capable to produce some hormones which induces the proliferation of roots and root hair that increase nutrient absorbing surfaces as well as produce organic acids, which solublize inorganic and organic forms of mineral elements.

\section{N, P, K, Fe, Mn and Zn uptake by tomato plants as affected by applied treatments}

Data given in Tables 10 and 11 indicate a positive significant effect on the nutritional status of tomato plants due to the relatively high nutrient contents in their tissues as a result of increasing applied rates of vermicompost, which may combined with elemental sulphur as agrochemical soil amendment and ascorbic acid levels as antioxidant defense in plant cells. The increases in some essential nutrients are in agreement with the results of Devlin and Witham (1985), who reported that the nutrient increases of $\mathrm{N}, \mathrm{P}, \mathrm{K}, \mathrm{Ca}$, $\mathrm{Zn}, \mathrm{Mn}, \mathrm{Fe}$ and $\mathrm{Cu}$ in tomato leaves may be due to the effect of $\mathrm{Zn}$ on biosynthesis of auxin (IAA), which promote rooting process, and consequently the amounts of mineral elements absorbed as well as their translocation to the different parts of plant. Furthermore, the responsibility for enhancing plant growth may be attributed to the effect of micronutrients on physiological processes such as chlorophyll content and activity of enzymes (Amberger, 1979 and Nour et al., 1984). Such favourable condition affects different physiological and metabolic functions of plant organs, consequently contents of endogenous gibberellins (Abed et al., 1987b). Increasing the measured growth characters (plant height, number of leaves plant ${ }^{-1}$ and dry weight plant $^{-1}$, etc...) was also achieved due to the micronutrients to be easily absorbed by the plant roots from soil media. Increasing No. of leaves plant ${ }^{-1}$ (Table 7) may be attributed to the stimulating effect of the released micronutrients on plant growth and their role in electron transmission from water to chlorophyll and producing oxygen gas in the photosynthesis. 
TABLE 8. Tomato yield as influenced by the levels of vermicompost, elemental sulphur and ascorbic acid (the average of the two successive growing seasons)

\begin{tabular}{|c|c|c|c|c|c|c|c|}
\hline \multirow{2}{*}{ Treatment } & & \multicolumn{6}{|c|}{ Fruit yield parameters } \\
\hline & \multirow{3}{*}{$\begin{array}{l}\text { Applied-S (kg/ } \\
\text { fed) }\end{array}$} & \multicolumn{3}{|c|}{ Fruit yield/ plant (kg) } & \multicolumn{3}{|c|}{ Fruit yield (ton/fed) } \\
\hline \multirow{6}{*}{0} & & \multicolumn{6}{|c|}{ Ascorbic acid $\left(\mathrm{mgL}^{-1}\right)$} \\
\hline & & 0 & 150 & 300 & 0 & 150 & 300 \\
\hline & 0 & 1.15 & 1.16 & 1.17 & 8.34 & 8.98 & 9.28 \\
\hline & 50 & 1.53 & 1.55 & 1.57 & 11.75 & 12.05 & 12.50 \\
\hline & 250 & 1.79 & 1.81 & 1.83 & 14.81 & 15.15 & 15.64 \\
\hline & 450 & 1.90 & 1.93 & 1.96 & 17.96 & 18.20 & 18.69 \\
\hline \multirow{4}{*}{10} & 0 & 2.32 & 2.34 & 2.36 & 10.63 & 11.05 & 11.60 \\
\hline & 50 & 2.49 & 2.51 & 2.54 & 12.35 & 12.80 & 13.39 \\
\hline & 250 & 2.70 & 2.72 & 2.75 & 14.90 & 15.53 & 16.08 \\
\hline & 450 & 2.94 & 2.97 & 3.00 & 18.10 & 18.75 & 19.41 \\
\hline \multirow{4}{*}{15} & 0 & 2.38 & 2.41 & 2.43 & 12.10 & 12.71 & 13.35 \\
\hline & 50 & 2.57 & 2.60 & 2.62 & 15.98 & 16.88 & 17.52 \\
\hline & 250 & 2.74 & 2.77 & 2.79 & 17.20 & 18.05 & 18.94 \\
\hline & 450 & 3.00 & 3.04 & 3.07 & 20.24 & 21.29 & 22.20 \\
\hline \multirow{4}{*}{20} & 0 & 2.54 & 2.55 & 2.56 & 16.86 & 17.63 & 18.58 \\
\hline & 50 & 2.76 & 2.79 & 2.81 & 19.95 & 21.99 & 23.01 \\
\hline & 250 & 2.95 & 2.99 & 3.02 & 24.84 & 25.90 & 26.85 \\
\hline & 450 & 3.21 & 3.26 & 3.29 & 30.54 & 31.62 & 32.89 \\
\hline \multirow{7}{*}{ L.S.D.at 0.05} & $\mathrm{OM}$ & \multicolumn{3}{|c|}{0.9099} & \multicolumn{3}{|c|}{2.0653} \\
\hline & $\mathrm{S}$ & \multicolumn{3}{|c|}{0.8287} & \multicolumn{3}{|c|}{1.0108} \\
\hline & $\mathrm{AC}$ & \multicolumn{3}{|c|}{1.6575} & \multicolumn{3}{|c|}{2.0216} \\
\hline & $\mathrm{OM} * \mathrm{~S}$ & \multicolumn{3}{|c|}{0.6851} & \multicolumn{3}{|c|}{1.0007} \\
\hline & $\mathrm{OM}^{*} \mathrm{AC}$ & \multicolumn{3}{|c|}{ N. S } & \multicolumn{3}{|c|}{ N. S } \\
\hline & S*AC & \multicolumn{3}{|c|}{ N. S } & \multicolumn{3}{|c|}{ N. S } \\
\hline & $\mathrm{OM}^{*} \mathrm{~S} * \mathrm{AC}$ & \multicolumn{3}{|c|}{ N.S } & \multicolumn{3}{|c|}{ N.S } \\
\hline
\end{tabular}

However, the greatest values of the studied nutrients in the tissues of tomato were associated with plants supplied by vermicompost at the rate of $20 \mathrm{~m}^{3} \mathrm{fed}^{-1}$ in combination with elemental sulphur at a level of $250 \mathrm{~kg} \mathrm{fed}^{-1}$ and ascorbic acid at level of $300 \mathrm{mg} \mathrm{L}^{-1}$. The elements uptake by tomato plants are more related to the released available nutrients and their easily mobility towards the plant roots. Such surpassed effect of the applied treatments, especially at the combined ones, is more associated with ameliorated soil $\mathrm{pH}$ due to the added $\mathrm{S}$ as well as to the relatively high contents released active organic substances that enhancing more released nutrients or their solubilization from both native and added sources, besides the favourable biological conditions that are keeping them in available forms for extended period and their mobility for uptake by plant roots. These findings are in harmony with those outlined by Hala et al., (2002) found that vermicompost is an efficient source of plant nutrients and that they are less likely to produce salinity stress in container as compared to compost and synthetic fertilizers. So, the combined treatments at the highest rates of vermicompost, and sulphur combined with ascorbic acid may exhibited a superior effect due to possible improving of soil physico-chemical properties that positively affect the nutrients availability as well as maintaining a suitable soil moisture regime and positive effect on the biological activity in soil. Also, such favourable effect could extends to reduce soil $\mathrm{pH}$, mainly due to the integrated action of the released active organic acids and S-transformation to 
$\mathrm{H}_{2} \mathrm{SO}_{4}$, respectively, besides the possible released phosphate ions by sulfate ions (El-Tapey and Hassan, 2002). It is noteworthy to mention that the nutrient contents in plant tissues were, in general, extending parallel close to the corresponding available nutrient contents in the studied soil, as shown in Tables 5 and 6. Also, such favourable effect of both applied $\mathrm{S}$ and vermicompost as combined treatments may attributed to the reduction in soil $\mathrm{pH}$ which improved the solubility and availability of nutrients for plant roots which was positively reflected on the nutrient contents in plant tissues (Rady, 2011). In this concern, Abdallah et al. (2010) showed that S deficiency for field-grown oilseed rape can reduce nitrogen use efficiency (NUE: ratio of harvested $\mathrm{N}$ to $\mathrm{N}$ fertilization) and that $\mathrm{N}$ deficiency can also reduce sulphur use efficiency (SUE). Also, it had a great extent favourable effect on the mobilization of the released nutrients that could be explained by many aspects, i.e., increasing the released macronutrient contents through the decomposition of the native sources, reduction of nutrient fixation and forming the stable complexes with humic substances supplied and keeping them in available forms for extended period and mineralization processes as well as minimizing their possible lose by leaching process through such a relatively coarse textured soil (Shanmugam and Veeraputhran, 2001).

Actually, the quality of tomato production is usually evaluated according to the purpose of which final product is used, i.e., either fruit or quality. In addition, the environmental conditions and agro-management practices, including nutrition status as related to the applied nutrient sources, are of the greatly effective

TABLE 9. Fruit quality parameters of tomato as influenced by the levels of applied vermicompost, elemental sulphur and ascorbic acid (the average of the two successive growing seasons)

\begin{tabular}{|c|c|c|c|c|c|c|c|c|c|c|c|c|c|}
\hline \multicolumn{2}{|c|}{ Treatment } & \multicolumn{12}{|c|}{ Fruit quality parameters } \\
\hline \multirow[t]{3}{*}{$\begin{array}{c}\text { Vermicompost } \\
\mathbf{m}^{3} / \text { fed. }\end{array}$} & \multirow[t]{3}{*}{$\begin{array}{l}\text { Applied-S } \\
\text { (kg/fed) }\end{array}$} & \multicolumn{3}{|c|}{ Fruit firmness (Ibs) } & \multicolumn{3}{|c|}{$\begin{array}{c}\text { Total soluble } \\
\text { solids\% (TSS) }\end{array}$} & \multicolumn{3}{|c|}{ Citric acid \% } & \multicolumn{3}{|c|}{ Total sugar $\%$} \\
\hline & & \multicolumn{12}{|c|}{ Ascorbic acid $\left(\mathrm{mgL}^{-1}\right)$} \\
\hline & & 0 & 150 & 300 & 0 & 150 & 300 & 0 & 150 & 300 & 0 & 150 & 300 \\
\hline \multirow{7}{*}{0} & 0 & 5.82 & 6.00 & 6.16 & 6.97 & 6.69 & 6.54 & 0.30 & 0.31 & 0.32 & 0.98 & 0.99 & 1.01 \\
\hline & 50 & 6.17 & 6.40 & 6.53 & 6.59 & 6.28 & 6.12 & 0.32 & 0.33 & 0.34 & 1.14 & 1.16 & 1.18 \\
\hline & 250 & 6.50 & 6.76 & 7.00 & 6.15 & 5.83 & 5.68 & 0.36 & 0.38 & 0.40 & 1.34 & 1.37 & 1.40 \\
\hline & 450 & 6.88 & 7.16 & 7.36 & 5.67 & 5.34 & 5.17 & 0.38 & 0.41 & 0.42 & 1.40 & 1.44 & 1.47 \\
\hline & 0 & 5.94 & 6.15 & 6.28 & 6.85 & 6.56 & 6.40 & 0.34 & 0.36 & 0.37 & 1.12 & 1.14 & 1.15 \\
\hline & 50 & 6.32 & 6.59 & 6.75 & 6.45 & 6.14 & 5.97 & 0.36 & 0.38 & 0.40 & 1.35 & 1.38 & 1.40 \\
\hline & 250 & 6.73 & 7.03 & 7.31 & 5.97 & 5.65 & 5.47 & 0.39 & 0.42 & 0.44 & 1.63 & 1.69 & 1.72 \\
\hline \multirow[t]{4}{*}{10} & 450 & 7.12 & 7.44 & 7.67 & 5.50 & 5.16 & 4.95 & 0.42 & 0.45 & 0.47 & 1.95 & 1.88 & 1.92 \\
\hline & 0 & 6.52 & 6.74 & 6.92 & 6.05 & 5.74 & 5.55 & 0.39 & 0.41 & 0.43 & 1.19 & 1.22 & 1.24 \\
\hline & 50 & 6.93 & 7.26 & 7.41 & 5.63 & 5.28 & 5.09 & 0.42 & 0.44 & 0.46 & 1.45 & 1.49 & 1.52 \\
\hline & 250 & 7.38 & 7.78 & 8.03 & 5.17 & 4.81 & 4.60 & 0.45 & 0.48 & 0.50 & 1.75 & 1.80 & 1.83 \\
\hline \multirow[t]{4}{*}{15} & 450 & 7.85 & 8.32 & 8.56 & 4.68 & 4.29 & 4.08 & 0.48 & 0.51 & 0.53 & 2.12 & 2.18 & 2.22 \\
\hline & 0 & 7.02 & 7.30 & 7.48 & 5.09 & 4.74 & 4.53 & 0.44 & 0.46 & 0.48 & 1.30 & 1.33 & 1.36 \\
\hline & 50 & 7.43 & 7.81 & 8.04 & 4.64 & 4.30 & 4.11 & 0.47 & 0.50 & 0.52 & 1.57 & 1.62 & 1.65 \\
\hline & 250 & 7.94 & 8.38 & 8.65 & 4.11 & 3.72 & 3.50 & 0.51 & 0.54 & 0.56 & 1.90 & 1.97 & 2.01 \\
\hline \multirow[t]{6}{*}{20} & 450 & 8.45 & 8.96 & 9.21 & 3.52 & 3.10 & 2.85 & 0.55 & 0.58 & 0.61 & 2.26 & 2.32 & 2.36 \\
\hline & $\mathrm{OM}$ & & 0.0058 & & & 0.2817 & & & 0.0135 & & & 0.0167 & \\
\hline & $\mathrm{S}$ & & 0.0049 & & & 0.1470 & & & 0.0031 & & & 0.0077 & \\
\hline & $\mathrm{AC}$ & & 0.0097 & & & 0.2940 & & & 0.0062 & & & 0.0154 & \\
\hline & $\mathrm{OM}^{*} \mathrm{~S}$ & & 0.0041 & & & 0.1280 & & & 0.0031 & & & 0.0045 & \\
\hline & $\mathrm{OM}^{*} \mathrm{AC}$ & & N. S & & & N. S & & & N. S & & & N. S & \\
\hline \multirow[t]{2}{*}{ L.S.D.at 0.05} & $\mathrm{~S} * \mathrm{AC}$ & & N. S & & & N. S & & & N. S & & & N. S & \\
\hline & $\mathrm{OM} * \mathrm{~S} * \mathrm{AC}$ & & N. S & & & N. S & & & N. S & & & N. S & \\
\hline
\end{tabular}


TABLE 10. Macro nutrient contents in tomato plants leaves as influenced by the levels of applied vermicompost, elemental sulphur and ascorbic acid (the average of the two successive growing seasons)

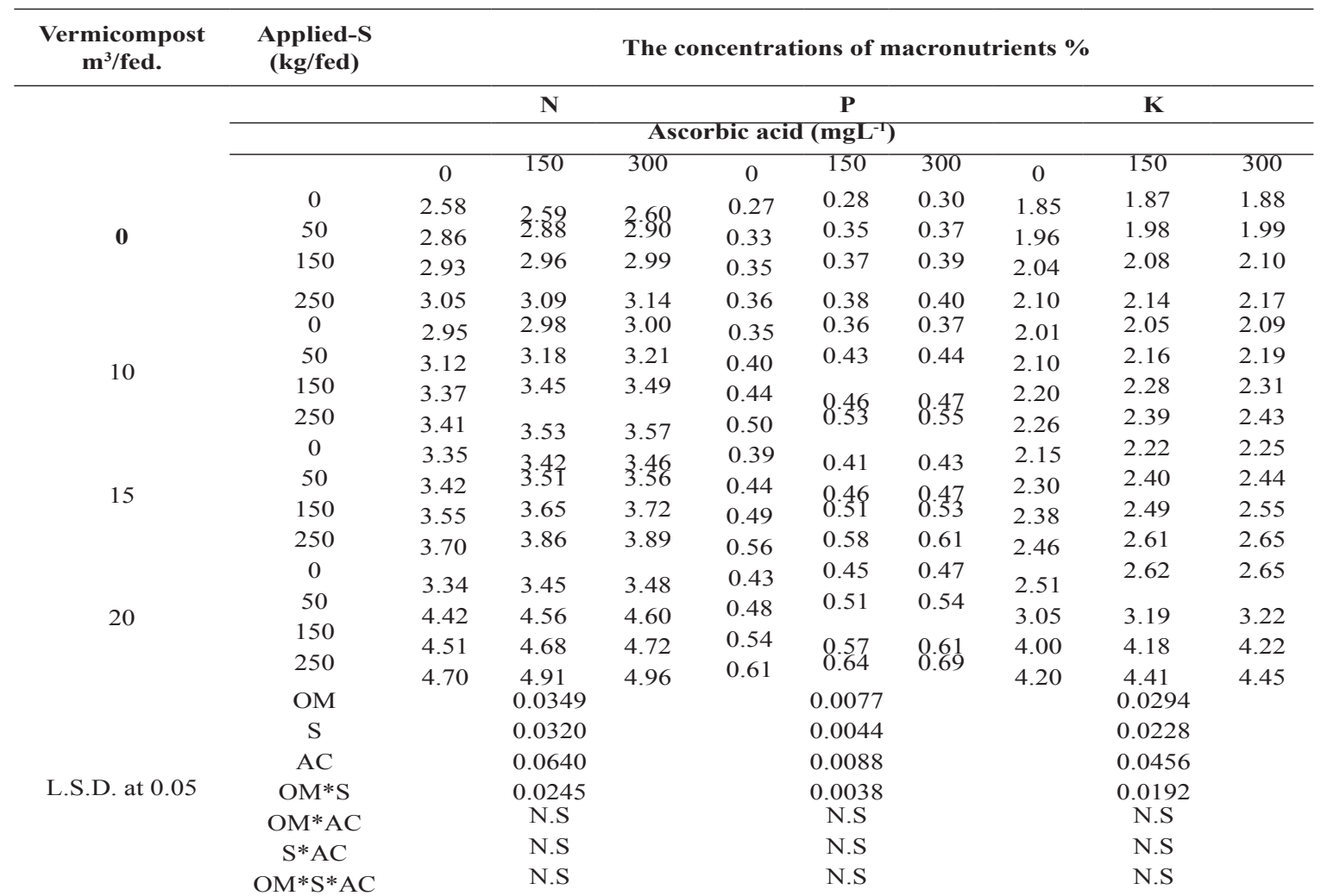

TABLE 11. Micro nutrient contents in tomato plants leaves as influenced by the different levels of applied vermicompost, elemental sulphur and ascorbic acid (the average of the two successive growing seasons)

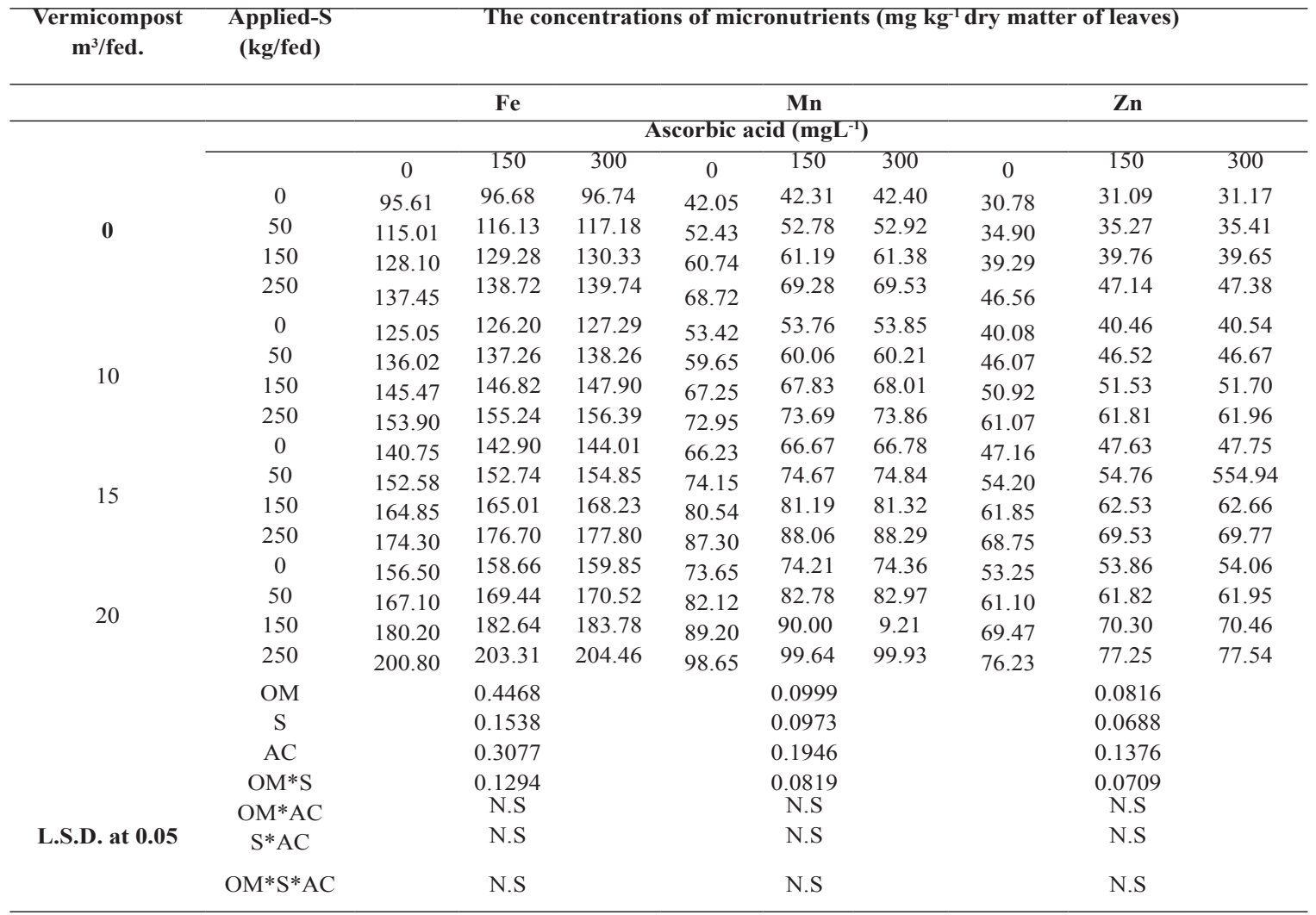

Egypt. J. Soil Sci. 58, No.2 (2018) 
factors through influencing biochemical or physiological processes. Thus, the content of organic constituents, which is accumulated or stored in tissues of plants, should be related to photosynthetic activity of plants and translocation rate of photosynthesis to the indicated plant parts (Mengle and Kirkby, 1987). This may suggest a close combination between growth and nutritional status parameters with tomato yield and its quality. If this is true, the selection for a practical source and soil used could be suggested depending on the economical point of view. Also, there was a similar trend for the parameters of bulb quality in the used soil types. This behavior suggests that applying vermicompost, elemental sulphur and ascorbic acid may represents the more suitable agro-management practice due to their effect to produce higher values of fruit firmness Ibs, total soluble solids $\%$, ascorbic acid, citric acid \% and total sugar $\%$ as well as nutrient contents in tomato tissues. This is possibly due to improving both plant growth and its nutritional status, which are more related to nutrients availability in soil.

Finally, it could be concluded that the effective role of the used vermicompost, elemental sulphur and ascorbic acid was not only positive effect on soil fertility status but also was positively reflected on tomato yield and its quality. Also, such applied organic and inorganic soil amendments had a longterm positive agronomic value due to its capacity to gradually liberate available plant nutrients. The integrated supply of nutrients through organic and inorganic sources could be an effective practice of nutrient management by using organic substances and elemental sulphur. Moreover, this approach is not only a source of suitable farmers income for due to increasing plant production in calcareous soils in nature, but also alleviate the potential hazardous of soil salinity conditions.

Also, the applied vermicompost leads to improvement in tomato quality and alleviated the possible fears of nitrogenous fertilizer as a chemical pollution for tomato as a fresh fruit vegetable. That means its application participate in solving for the problems of chemical residues in the export market commodities. From the economical point of view, the use of vermicompost decreases the amounts of used chemical fertilizers, that leads to higher yield and better quality of tomato with a relatively lower cost.

In addition, under the current experimental conditions, it could be concluded that the work within hand granted evidence to the effective role of applied vermicompost at the rate of $20 \mathrm{~m}^{3} \mathrm{fed}^{-1}$ in combination with elemental sulphur at the rate of $250 \mathrm{~kg} \mathrm{fed}^{-1}$ and ascorbic acid as foliar spray at the rate of $300 \mathrm{mg} \mathrm{L}^{-1}$. Such combined treatment achieved the greatest values, from the economical point of view, for growth parameters, yield and its quality of tomato plants and decreases production costs. This treatment also overcomes the adverse conditions of the newly reclaimed calcareous soils.

\section{References}

Abdallah, M., Dubousset, L., Meuriot, F., Etienne, P. , Avice, J.C. and Ourry, A. (2010) Effect of mineral sulphur availability on nitrogen and sulphur uptake and remobilization during the vegetative growth of Brassica napus L. Journal of Experimental Botany, 123, $1-12$.

Abed, T.A., Abd-Alla, I.M. and Abo-Sedera, F.A. (1987b) Effect of some micronutrients foliar spray and salinity stress on pea (Pisum sativum L.). II. Flowering behavior, yield and its quality. Ann. Agric. Sci., Fac. of Agric. at Moshtohor, Zagazig Univ., 25 (2), 1057-1070.

Abou El-Magd, M.M. Hoda; Mohamed, A. and Fawzy,Z.F. (2005) Relationship growth, yield of broccoli with increasing $\mathrm{N}, \mathrm{P}$ or $\mathrm{K}$ ratio in a mixture of NPK fertilizers (Brassico oleracea var italica plenck). Annals of Agriculture Science, Moshtohor, 43 (2),791-805.

Abou Zied, M.M.A.; Habashy, N.R. and Wahdan,A.A.A. (2005) Utilization of some organic polymers and humic acids for improving a sandy soil productivity of peanut and their residual effects on the next crop of faba bean. Fayoum J. Agric. Res. \& Dev., 19 (2), $42-55$.

Ahmed, H.A. (2009) Effect of different nitrogen and sulphur fertilizer levels on growth, yield and quality of onion (Allium cepa, L). Jordan Journal of Agriculture Sciences, 5(2),155- 165.

Ali, Z.A. (2002) Effect of foliar application with ascorbic acid on vegetative growth and some biochemical constituents of tomato plants. J. Agric. Sci., Mansoura Univ., 27 (10),6765-6775.

Aly, Mona M.M. (2003) Biological studies on some associative nitrogen fixing bacteria. M. Sc. Thesis, Fac. of Agric., Cairo Univ., Giza, Egypt.

Al-Qubaie, A.I. (2002) Response of Ficus nitida L. seedlings to the application of some antioxidants under soil salinity conditions. Minia J. Agric. Res. \& Develop., 22 (3), 235-254.

Amberger,A. (1979) Foliar application of micronutrients uptake and incorporation into metabolism. Proc. $2^{\text {nd }}$

Egypt. J. Soil Sci. 58, No. 2 (2018) 
Workshop on "Micronutrients and Plant Nutrition", Mariut, Egypt.

A.O.A.C. (1990). Association of Official Analytical Chemists, Official Methods of Analysis. 17th ed., Washington, D.C., U.S.A.

Ashmaye, S.H., Shaban,Kh.A. and Abd El-Hader,M.G. (2008) Effect of mineral nitrogen, sulphur, organic and bio-fertilizers on maize productivity in saline soil of Sahl El-Tina. Minufiya, J. Agric. Res., 33 (1),195-209.

Askar, F.A., Marei, S. and El-Zaher, H. (1994) Sewage sludge as natural conditioner for newly reclaimed soils. 1: Effect on soil moisture retention characteristics and pore size distribution. Egypt. J. Soil Sci., 34,67.

Awad, E.A.M; Mostafa, M.M. and Helmy,A.M. (2000) Macro and Micronutrient contents of maize plant as affected by the application of some organic wastes and sulphur. Zagazig J. Agric. Res., 27(4),1015-1029.

Awadalla, A.A. Salib, M.M. and Ibrahim,Sh.B. (2003) Response of maize yield grown on calcareous soil to some organic and inorganic amendments under irrigation with saline drainage water. Egypt. J. Appl. Sci., 18 (3), 366-381.

Ayers, R.S. and Westcot,D.W. (1985) Water quality for agriculture, irrigation and drainage. Paper No. 29, FAO, Rome, Italy.

Bacilio, M., Vazquez, P. and Bashan, Y. (2003) Alleviation of noxious effect of cattle ranch composts on wheat seed germination by inoculation with Azospirillum spp. Biology and Fertility of Soil, 38 (4),261.

Basyouny, E.A. (2005) Effect of chelated micronutrients combined with sulphur or organic manures on wheat production grown on a calcareous soil. Egypt. J. Appl. Sci., 20 (9), 375-387.

Black, C.A., Evans, D.D., Ensminger; L.E., White,J.L. and Clark,F.E. (1965) Methods of Soil Analysis. Amer. Soc. Agron. Inc., Pub., Madison, Wisc., USA.

Cheng, F.J., Yang, D.Q. and Wu,Q.S. (1998) Physiological effects of humic acid on drought resistance of wheat. Chinese J. of Applied Ecology, 6 (4), 363-367.

Cox, D. A. (1993) Reducing nitrogen leaching-losses from containerized plants: the effectiveness of controlled-release fertilizers. Journal of Plant Nutrition, 16, pp. 533-545.

Devlin, R.M. and Witham, F.H. (1985) Plant Physiology. $4^{\text {th }}$ ed. CBS Publishers and Distribution, 485, Jain Bhawan, Bhola Nath Nagar, Shahdara. Delhi-110 032 (India), $443 \mathrm{pp}$.

Egypt. J. Soil Sci. 58, No.2 (2018)
Duncan, W.G. (1971) Leaf angle, leaf area and canopy photosynthesis. Crop. Sci., 11, 482-485.

Edwards, C.A. Edwards1(995) Historical overview of vermicomposting. Biocycle, 36 (1995), pp. 56-58.

Elade, Y. (1992) The use of antioxidants to control gray mould (Botrytis cineria) and white mould (Sclerotinia sclerotiorum) in various crops. Plant Pathol., 141, 417-426.

El-Foly, H.M.H. (2004) The productivity of potato plants as affected by different organic and inorganic fertilizers. Minia J. of Agric Sci., (34) 6, 285-305.

El Hady, O.A., Abd El Hady, B.M., Rizk, N.A. and El Saify, E.S. (2003) The potentiality for improviming plant-soil water relations in sandy soils using some synthesized Am Na (Or K) ATEA hydrogels. Egypt. J. Soil Sci., 43 (4), 547-566.

El-Saidi, M.T. (1997) Salinity and its effect on growth, yield and some physiological processes of crop plants. In: Strategies for improving salt tolerance in higher plants.

El Tapey, H.M.A. and Hassan, H.M. (2002) Effect of water salinity and zinc applications on zinc mobility and growth of sunflower and sudangrass plants grown on Nile alluvial and calcareous soils. Egypt. J. Appl. Sci., 17 (12), 840-849.

Fathi, A.I.; E.M. Gaffar; N.H. Omer and S.S. Behairy (2005) Interaction effect of sulphur and phosphorus on yield and nutrient contents of lentil. Egypt. $J$. Appl. Sci., 20 (2), 340-349.

Foyer, C.H. and Halliwell, B. (1976) The presence of glutathione and glutathione reductase in chloroplasts: A Proposed Role in Ascorbic Acid Metabolism Plants, 157, 239-244.

Gomaa, M.A. (1997) Response of wheat (Triticum aestivum L.) to seeding rate and nitrogen levels under sandy soil conditions. Egypt. J. Appl. Sci., 12 (2), 88-102

Hala, I. C., Larry, M. Z. and Tsutomu, O. (2003) Effects of earthworm casts and compost on soil microbial activity and plant nutrient availability. Soil Biolgy and Biochemistry, 35 (2), 295-302.

Hegazi, I.M.A. (2004) Maximizing wheat production in sandy soil by using some natural soil amendments. Egypt. J. Appl. Sci., 19 (4), 214-226.

Hidalgo, P. (1999) Earthworm castings increase germination rate and seedling development of cucumber. Mississippi Agricultural and Forestry Experiment Station, Research Report. 22 no. 6.

Higinbotham, N.; Bud, E. and Foster, R.J. (1967) Mineral ion contents and cell transmembranes electropotentials of peas and oat seedling tissues. 
Plant Physiol., 24, 37-46.

Hiscox, J.D. and Isrealstam, G.F. (1979) A method for the extraction of chlorophyll from leaf tissues without maceration. Can. J. Bot., 57, 1332-1334.

Kaplan, M.; Orman, S., Kadar, I. and Koncz, J. (2005) Heavy metal accumulation in calcareous soil and sorghum plants after addition of sulphur-containing wastes as a soil amendment in Turkey. Agric. Ecosyst. Environ., 111,41-46.

Klute, A. (Ed.) (1986) Methods of Soil Analysis. No. 9 Part 1, Amer. Soc. Agron., Inc. Madison, Wisconsin, USA.

Wheat under saline irrigation water. Egypt. J. Soil Sci., 35 (4), 439-451.

Lindsay, W.L. and Norvell, W.A. (1978) Development of DTPA soil test for Zn, Fe, Mn and Cu. Soil Sci. Soc. Am. J., 42,421.

Lui, S.X., Xiong, D.Z., Wu, D.B. (1991) Studies on the effect of earthworms on the fertility of red-arid soil. Advances in management and conservation of soil fauna, Proceedings of the 10th International Soil Biology Colloquium, held at Banglador, India, August 7-13..

McMullan, P.M.; Mcvetty,P.B.E. and Urguhart, A.A. (1998) Dry matter and nitrogen accumulation and redistribution and their relationship to grain yield and grain protein in wheat. Can. Plant Sci., 68, 311-322.

Mengle, K. and E.A. Kirkby 1987. Principles of Plant Nutrition. $4^{\text {th }}$ ed., International Potash Institute, Bern, Switzerland, 62,524.

Mohammed, S.S. (2004) Assessment of the relative effectiveness for some organic materials conjucted with mineral nitrogen on soil fertility status, yield and quality of wheat grown on a newly cultivated soil. Egypt. J. Appl. Sci., 19 (3), 298-310.

Mostafa, M.M. (2000): Nutrients availability as affected by applying agro-industrial wastes and sulphur to saline and non-saline soils. Egypt. J. Appl. Sci., 15 (11), 385-397.

Negm, M.A.; El-Zaher, H., Abd Elghani, M.M. and Salib, M.M. (2002a) Effect of commercial compost (Biotreasure) and sulphur added to a calcareous soil on: 1) Soil properties and fertility. Minufiya J. Agric. Res., 27 (2),369-379.

Negm M.A.; El-Zaher, H., Awad, M.S. and El-Sayed, M.H. (2002b) Effect of commercial compost (Biotreasure) and sulphur added to a calcareous soil on (II) Cereal productivity and nutrient uptake. Minufya J. Agric. Res., 27 (2), 381-390.

Nour, T.A.; Firgany, A.H. and Hussein,M.M. (1984) Studies on the effect of foliar nutrition with urea and some micronutrients. J. Agric. Res. Tanta Univ., 10 (3), 922-932.

Osman, A. Sh. and Ewees,M.S.A. (2008) The possible use of humic acid incorporation with drip irrigation system to alleviate the harmful effects of saline watwe on tomato plants. Fayoum J. Agric. \& Dev., 22 (1), 52-70.

Page, A.I.; Miller, R.H. and Keeney, D.R. (1982) Methods of Soil Analysis. Part II: Chemical and Microbiological Methods. $2^{\text {nd }}$ ed. Amer. Soc. Agron., Madison, Wisconsin, USA.

Pashanasi, B., Lavelle, P., Alegre, J. and Charpentier, F. (1996) Effect of the endogeic earthworm, Pontoscolex corethrurus on soil chemical characteristics and plant growth in a lowinput tropical agroecosystem. Soil Biology \& Biochemistry, 28, 6, pp. 801-808.

Rady, M.M. (2006)Efficiency of growth and productivity of sunflower plants as affected by ascorbic acid under saline reclaimed soil conditions. The Second Conference on Farm Integrated Pest Management, 16-18 Jan., pp. 186 -200.

Rady, M.M. (2011). Effects on growth, yield and fruit quality in tomato (Lycopersicon esculentum Mill.) using a mixture of potassium humate and farmyard manure as an alternative to mineral-N fertilizer. Journal of Horticultural Science and Biotechnology, 86 (3), 249-258.

Rady, M.M. and Migawer, Ekram A. (2010) Possibility of improving growth, physiological behavoiur and yield of canola plants cultivated in saline reclaimed soils with application of humic and ascorbic acids. Minufiya J. Agric. Res., 35 (3), 863-883.

Rautenkranz, A.; Machler, F., Martinoia,E. and Oertli, J. (1994) Transport of ascorbic acid dehydroascorbic acid across protoplast and vacuole membranes isolated from barley (Hordeum vulgaris L., Gebrel cv.) leaves. Plant Physiol., 106, 187-193.

Saciragic and Dzelilovic, M. (1986) Effect of worm compost on soil fertility and yield of vegetable crops cabbage leeks and sorghum hybrid yield. Agrohemija, 3 , pp. 343-351.

Sarker, M.C., Singh,M. and Nath,J. (1992) Influence of farmyard manure on soil structure and some related soil properties. Indian Soc. Soil Sci., 21, 227-229.

Shahin, R. and Suliman, A.S. (1998) Transformation of sulphur-blended urea and ammonia volatilization in sandy soils. Fayoum J. Agric. Res. \& Dev., 12 (1), 66-77.

Shanmugam, P.M. and R. Veeraputhran (2001) Effect of organic and inorganic $\mathrm{N}$ and $\mathrm{Zn}$ application on soil fertility and nutrient uptake of rabi rice (Oryza 
sativa). Madras Agric. J., 88 (7-9),514-517.

Shuqin, W., Kang; Y., Wang, D., Liu, Sh. and Feng, L. (2007) Effect of drip irrigation with saline water on tomato (Lycopersicon esculentum Mill) yield and water use in semi-humid area. Institute of Geographical Sci. and Natural Resource Res., Beijing, China.

Snedecore, G. W. and Cochran, W. G. (1980) Statistical Methods. $7^{\text {th }}$ ed. Iowa State Univ., Press, Amer., Iowa, U.S.A.

Soil Survey Staff (1999) Soil Taxonomy. A Basis System of Soil Classification for Making and Interpreting Soil Surveys. Second edition, U.S. Department of Agriculture, Natural Resources Conservation Service, U.S.D.A., Agriculture Handbook No. 436.

Soltanpour, P.N. and Schwab, A.B. (1977) A new soil test for simultaneous extraction of macronutrients in alkaline soils. Comm. Soil Sc. and Plant Anal., 8, 195.

Sys, C. and Verheye, W. (1978) An attempt to the evaluation of physical land characteristics for irrigation to the FAO framework for land evaluation. Int. 1, Trai. Cent. Post Grad. Soil Sci., Ghent, Belgium.

Takker, P.N. and C.D. Walker (1993) The distribution and correction of zinc deficiency. In: Zinc in Soils and Plants. Robson, A.D. (Ed.), Kluwer Acad.
Publ., Dordrecht, pp. 151-165, The Netherlands.

Tomati, A. Grapelli and Galli, E. (1987) The hormonelike effect of earthworm casts on plant growth. Biology and Fertility of Soils, pp. 288-294.

Tomati, U. E. Galli, Grappelli, A. and Hard, J.S. (1994) Plant metabolism as influenced by earthworm casts. Mitteilungen aus dem Hamburgischen Zoologischen Museum and Institute, 89, 2, pp. 179-185.

Tsadilas, C.D.; Matsi, T.N. and Barbayiannis Dimoyiannis, D. (1995) Influence of sewage sludge application on soil properties and on the distribution and availability of heavy metal fractions. Commu. Soil Sci. and Plant Analysis, 26, 15-16.

Van Schouwenberg, J.Ch. (1968) International Report of Soil and Plant Analysis. Lab. of Soil and Fert. Agric., Wageningen Univ., Netherlands.

Wilde, S.A.; Corey; R.B., Lyer, J.G. and Voigt, G.K. (1985) Soil and Plant Analysis for Tree Culture. Oxford and IBM Publishers. New Delhi. India. $3^{\text {rd }}$ ed., 93-106 pp. 


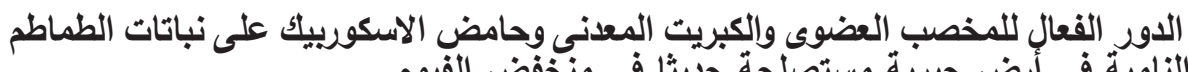

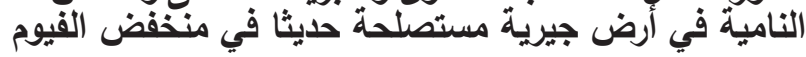
عبد الناصر أمين - أحمد عبد الحفيظ و محمد صابر على عويس

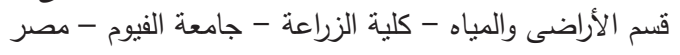

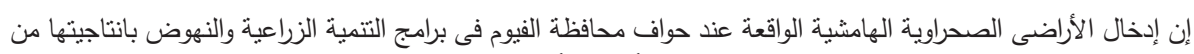

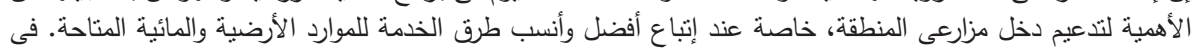

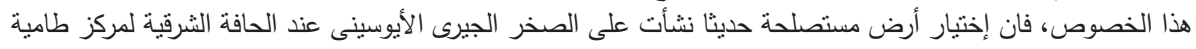

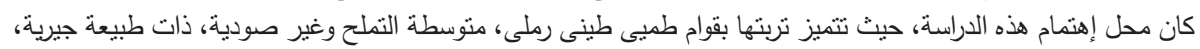

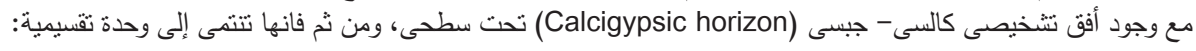
.Typic Calcigypsids, fine loamy, mixed, hyperthermic, moderately deep

وطبقا لنظام التقييم الكمى فانها تنتمى إلى رتبة الأراضي المتوسطة الصلاحية للزراعة:Moderately suitable

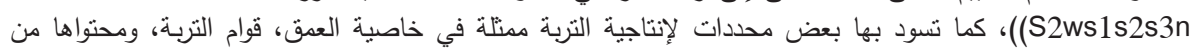
، CaCO 3

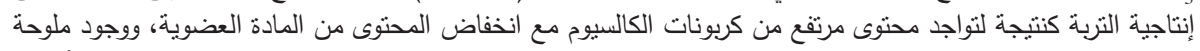

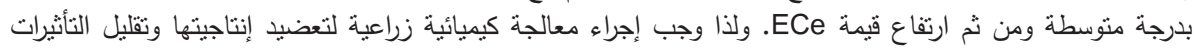

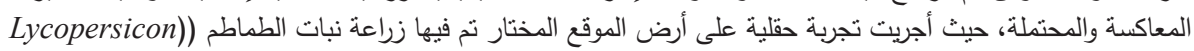
esculentum, C.v. 1077 hybrid

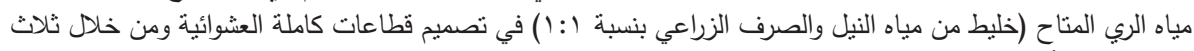

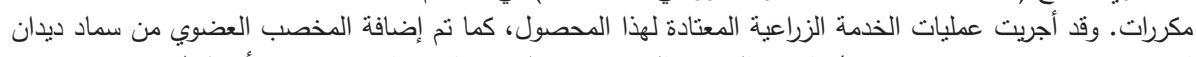

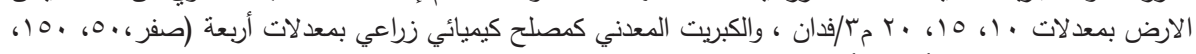

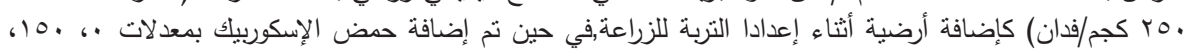

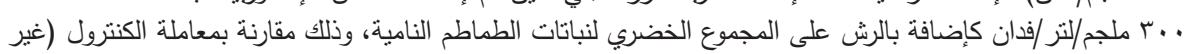

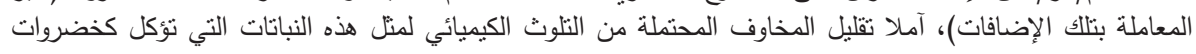
طازجة وكذا المخاطر البيئية.

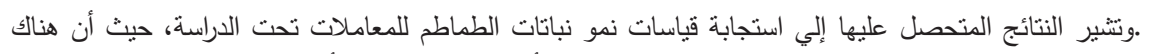

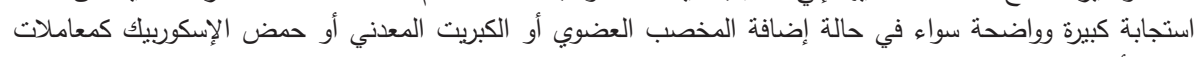

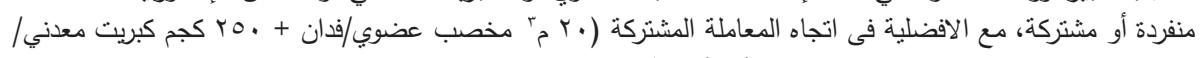

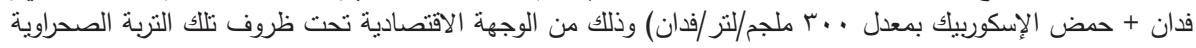

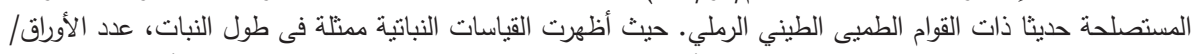

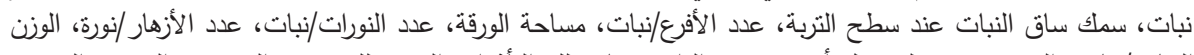

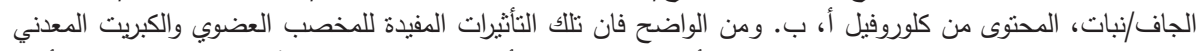

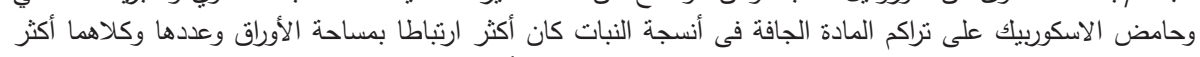

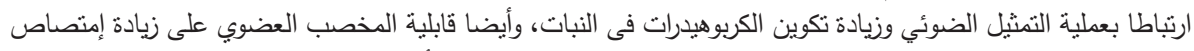

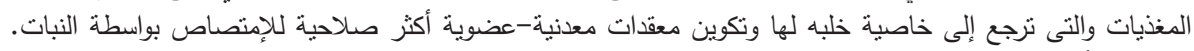

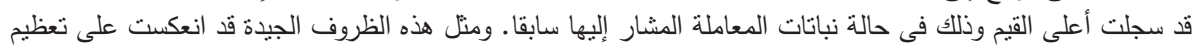

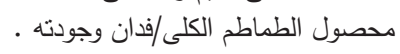

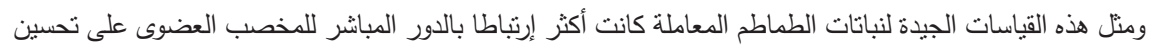

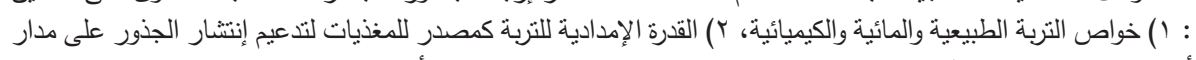

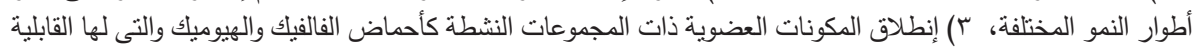

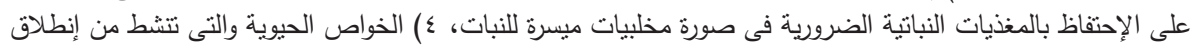

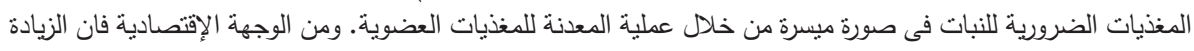

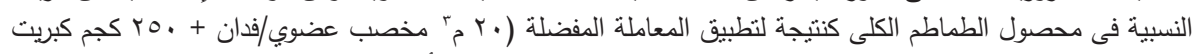

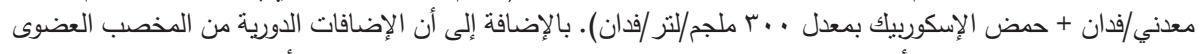

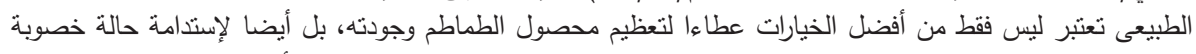

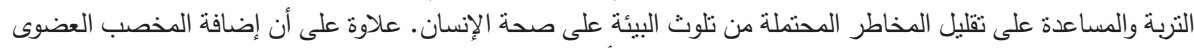
للتربة يمثل حلا لمشاكل بقايا المكونات الكيميائية فى سلع الأسواق التصدئة التصيرية. 